\title{
A THIRD EXAMPLE OF THE BLOOD GROUP ANTIBODY ANTI-k
}

\author{
BY \\ HAL CRAWFORD \\ From the Medical Research Council Blood Transfusion Research Unit, Postgraduate Medical \\ School of London
}

(RECEIVED FOR PUBLICATION SEPTEMBER 22, 1952)

Levine, Wigod, Backer, and Ponder (1949) and Levine, Kuhmichel, and Wigod (1952) have described two examples of an antibody, "antiCellano," which reacts with all blood samples except those from individuals belonging to the rare genotype KK. The first example was found in a woman whose infant had mild haemolytic disease of the newborn; the second was found in a patient who had received several transfusions. The first serum agglutinated red cells suspended in saline, reacting most strongly at $37^{\circ} \mathrm{C}$.; the second serum gave weak agglutination in saline but gave distinct reactions when the indirect Coombs test was used. The present note records the detection of a third example of anti-k.

\section{Case Report}

The patient, Mrs. G., had been well until 1947 ; more than 10 years before that she had had three normal pregnancies. In 1947 she had a haematemesis and received a transfusion of blood from two donors. In 1949 she had a partial gastrectomy, and at operation was found to have a malignant ulcer. No further transfusion was given at this time. In September, 1951, a laparotomy was performed ; numerous secondaries were found in the peritoneal cavity and the abdomen was closed. Before operation the patient received a drip transfusion of 2 pints of group O Rh-negative blood. During the operation there was considerable haemorrhage, and, as no fresh $\mathrm{Rh}$ negative blood was immediately available, $\mathrm{Rh}$-positive blood was used, one bottle being transfused during operation and a second bottle after operation. The total time taken to transfuse the four bottles of blood was about 12 hours. The red cells of all the four bottles appeared to be compatible with the patient's plasma in vitro. During the day after transfusion only about $2 \mathrm{oz}$. of urine was passed, and, on the following day when the patient was catheterized, $12 \mathrm{oz}$. of heavily pigmented urine was passed. During the next few days the patient passed only 1 to $3 \mathrm{oz}$. of urine a day, and five days after operation her blood urea level was found to be $306 \mathrm{mg}$./ $100 \mathrm{ml}$. She died on the seventh day after operation.
Because the patient developed anuria it was 0 suspected that incompatible blood might have been given and the compatibility tests were re- $\vec{T}$ peated. At the same time samples were submitted $\frac{\mathbb{O}}{O}$ to this Unit for investigation. These showed that the pre-transfusion sample of serum contained anti-D with a titre of 8 in albumin. The serum $\vec{\varphi}$ did not agglutinate D-positive cells suspended in of saline, though it sensitized them strongly to an anti-globulin serum. A sample of serum taken 0 six days after transfusion had an anti-D titre of 8 in saline and 1,024 in albumin. In the course of testing this latter sample it was observed that, $\frac{0}{8}$ unlike the pre-transfusion sample of serum, it $\stackrel{\square}{\complement}$ reacted with $D$-negative blood samples. It was $\overrightarrow{\overrightarrow{0}}$ concluded that a further antibody had developed 3 in the patient's serum as a result of the last transfusion. This antibody had a titre of 2 in saline? and 4 in albumin, and was found to be more active at $37^{\circ} \mathrm{C}$. than at lower temperatures. The serum reacted with six out of six group $O \mathrm{Rh}-\frac{3}{3}$. negative samples whose full blood groups were known, and it was apparent that the antibody could not be one of the common ones. It was not possible to test the red cells of the patient 5 because in the meantime she had died. It seemed $\frac{D}{O}$ possible that the antibody might be anti-k, and, since no Rh-negative donors of the type KK were o available, it was necessary to isolate the antibody. $N$ This was done by adsorbing it on to $R h$-negative $N$ red cells at $37^{\circ} \mathrm{C}$. and then eluting it off at $56^{\circ} \mathrm{C}$. $\mathrm{\omega}$ into group AB serum. The eluate was tested against a panel of red cells of known types using $\stackrel{\circ}{\circ}$ the anti-globulin technique. Twenty-two blood samples were tested, of which three were $\mathrm{KK}$. Of the 19 samples which reacted, 16 belonged to the genotype $\mathrm{kk}$, and three to the genotype $\mathrm{Kk}: \mathbb{\mathbb { D }}$ the three samples which did not react all belonged $\frac{}{\Phi}$ to the genotype KK. These findings provide very strong evidence of the presence of anti-k in the original serum $(\mathrm{p}=0.001)$. 


\section{Summary}

A third example of anti-k is described. The antibody developed after transfusion in a patient who had previously had three pregnancies and one transfusion. The antibody was weakly active in saline and albumin, and could best be detected by the indirect anti-globulin test.
I am grateful to Dr. P. L. Mollison for help in this investigation, and to Dr. J. N. Marshall Chalmers and Dr. A. E. Mourant for supplying samples of blood from donors of the genotype KK.

REFERENCES

Levine, P., Wigod, M., Backer, A. M., and Ponder, R. (1949). Blood, 4, 869 .

Kuhmichel, A. B., and Wigod, M. (1952). Ibid., 7, 251. 